\title{
Ovarian development in Meliponine bees (Hymenoptera: Apidae): the effect of queen presence and food on worker ovary development and egg production
}

\author{
Carminda da Cruz-Landim
}

\begin{abstract}
Morphological studies of Meliponine worker ovaries in five species indicated a possible stimulatory effect of the queen on ovary development and on the production of trophic eggs in some of them. There are also indications that the queen inhibits the production of fertile eggs by the workers. This inhibition may involve a delay in the development of fertile eggs by the worker, until she is out of direct contact with the queen, or a lack of ovary development in the queen's presence, as seen in Leurotrigona muelleri. The evolutionary tendency toward inability to produce fertile eggs has its extreme representation in the pupal worker ovary reabsorption found in Frieseomelitta silvestri. On the other hand, the finding, in some species, of dwarf queens with the basic number of ovarioles (four) in the ovaries, along with normal, trophically determined queens with larger numbers of ovarioles in the ovaries demonstrate the influence of food on this character, as in Apis mellifera.
\end{abstract}

\section{INTRODUCTION}

The Meliponinae are stingless, mainly neotropical highly eusocial bees. Division of reproductive work in the colonies leads to two female castes, one fertile (the queen) and another sterile, or partially sterile (the workers). This condition is frequently reflected in a marked dimorphism in ovarian development between queens and workers.

While in Apis mellifera (Apinae) this dimorphism is expressed as different numbers of ovarioles per ovary, in the Meliponinae it is expressed mainly by an increase in queen ovariole length. Although Sakagami et al. (1963) reported that all Meliponinae have four ovarioles per ovary, it is now known that this number may vary, at least in queens (Iwata and Sakagami, 1966, Camargo, 1974; CruzLandim et al., 1998). In workers, the basic number four, however, seems to be constant (Cruz-Landim et al., 1998).

A. mellifera workers may develop ovaries during the absence of the queen or when the colony population is very large (Groot and Voogd, 1954). It is thought that brood presence and inhibitory pheromones produced by the queen keep worker ovaries from functioning (Groot and Voogd, 1954; Butler, 1957; Kubisova and Hasbachova, 1978; Kubisova et al., 1982).

In Meliponinae the situation is more complex. In several species the workers present developed ovaries and produce oocytes, even in queenright colonies (Sakagami et al. 1963), but there are species (e.g., Leurotrigona muelleri) that, like A. mellifera, only develop ovaries during the queen's absence or in highly populated colonies. Workers of some species (e.g., Frieseomelitta silvestri and Duckeola ghiliani) never develop ovaries (Sakagami et al., 1963; Sakagami and Zucchi, 1968; Terada, 1974; Camillo-Atique, 1977; Staurengo da Cunha et al., 1989; Zucchi, 1993).
Workers whose ovaries develop in queenright colonies produce two kinds of oocytes: trophic oocytes that are eaten by the queen and functional oocytes that eventually develop into males (Beig, 1972; Staurengo da Cunha, 1978). Species that develop ovaries exclusively during the queen's absence only produce functional oocytes (Zucchi, 1993, 1994). Therefore, in most Meliponinae ovarian development in workers seems to be out of the queen's control, which agrees with the theory of ritualized instead of pheromonal dominance of queens over workers (Zucchi, 1993).

In some Meliponinae species, such as $P$. remota, two kinds of queens may be produced (Juliani, 1962; Imperatriz-Fonseca et al., 1997). Small or dwarf queens are produced in worker cells, and consequently have no trophic influence, while normal-sized queens are produced in queen cells that may harbor a larger quantity of food. The mode of caste determination in these species is said to be trophic; however, the production of queens that have not received differential alimentation suggests that the determination is genetic and that food only enhances some existing queen characteristics, as occurs in Melipona, considered to have genetic determination of castes. In these bees, a certain number of queens are born in each comb according to the number of gene pairs involved in the caste determination. However, only under optimal alimentary conditions will the full queen characters manifest. Underfed individuals with the queen genotype have underdeveloped queen characteristics (Kerr, 1950, Kerr et al., 1966).

The objective of the present work was to analyze ovary types in Meliponinae, examining some characteristics of their development during the post-embryonic phase, the effect of queen presence on worker ovary development and on the type of worker-produced egg. 
MATERIAL AND METHODS

The following Meliponinae species were studied in newly emerged and middle-aged workers, with light microscopy: Melipona quadrifasciata anthidioides, Scaptotrigona postica, Trigona spinipes, Plebeia remota, Leurotrigona muelleri, and Frieseomellita silvestri. Virgin queen ovaries from Plebeia remota, Trigona spinipes and Melipona quadrifasciata anthidioides were also studied. The ovaries of workers of Frieseomellita silvestri were studied in the last larval and pupal stages and early adulthood with light and transmission electron microscopy. At least three workers and one queen from each species were studied. Specimens of Leurotrigona muelleri fixed in Dietrich's solution were generously supplied by FFCL-USP, Ribeirão Preto.

Species present in our apiary (M. quadrifasciata anthidioides, S. postica and Frieseomelitta silvestri) were studied, and worker age controlled. Species from collections were separated by tegument coloration, assuming that the darker (middle aged, corresponding approximately to the worker nurse phase) specimens were older than the lighter.

When the bee was captured alive, the abdomen was separated from the body and fixed in $10 \%$ neutral formaldehyde, for light microscopy. The fixed material was embedded in historesin, and slides containing $6-\mu \mathrm{m}$ thick sections were routinely stained with hematoxylin and eosin. Some ovaries were dissected and whole mounts submitted to standard Feulgen reaction.

For transmission electron microscopy ovaries were dissected from immature and adult specimens and fixed in $2.5 \%$ glutaraldehyde in $0.1 \mathrm{M}$ cacodylate buffer, $\mathrm{pH} 7.2$, and post-fixed in $1 \%$ osmium tetroxide in the same buffer. Staining with uranyl acetate was done during dehydration and with lead citrate after cutting.

\section{RESULTS}

\section{Queens}

The queen of M. q. anthidioides has four ovarioles per ovary, while $T$. spinipes has about a dozen. Small (dwarf) and normal-sized queens were studied in P. remota. The dwarf queens had four ovarioles in each ovary and the normal-sized ones had six in one and eight in the other (Figure 1). In all cases virgin queen ovarioles were very long and slender, presenting the same diameter along almost the whole length, with the exception of the very proximal and distal ends from the place of attachment to the oviduct and terminal filament, respectively.

The ovarioles showed little differentiation in the virgin queens. In the basal portion, the germinative cells were arranged as cysts (Figure 1A,B), while in the distal many mitoses could be seen (Figure 1D). Signs of cyst degeneration were frequently seen, primarily in $P$. remota dwarf queens (Figure 1C).
Workers

The workers always had four ovarioles in each ovary. The ovaries were short and differently developed according to worker phase or bee species.

In workers that developed ovaries in the presence of a queen, the nurse workers had the most developed ovaries, generally showing one or two developing oocytes per ovary (Figure 1E,F). In Melipona one developing oocyte in each ovary was frequently found, and sometimes two in the same ovary (Figure 1G).

It is possible to differentiate trophic from functional eggs in the ovary. The trophic eggs in Melipona, for instance, are always bigger and more rounded than the functional ones are (Figure 1G). In S. postica, functional eggs are produced by late nurse workers, while young nurse workers produce mainly trophic eggs.

Middle-aged L. muelleri workers from orphan colonies generally have developed ovaries. Among 20 middleaged workers, four had developing oocytes in the ovary. In these workers, two had only one ovary with developing oocytes and two had developing oocytes in both ovaries. Since the specimens arrived at our laboratory in fixative, it was impossible to determine their age or whether they were young or old nurse bees.

In $F$. silvestri at the beginning of the larval stage, ovary development seemed to be normal (Figure 2A,B) with the ovarioles differentiating inside the ovary, but during pupation the ovarioles suffered an involutive process (Figure 2C,D). With transmission electron microscopy the degenerative process was found to be very similar to that observed by Hartfelder and Steinbrück (1997) in A. mellifera workers, only it seems to reach all ovarioles. Germinative cells became enclosed by a sheath of amorphous material, their nuclei shrunk and condensed, and electrondense structures appeared in the cell cytoplasm (Figure 2E). Later, the cells became filled with glycogen (Figure 2F), and finally showed lipid droplets and multimembranous bodies (Figure 2G). Relicts of the ovaries could be found in young workers of this species. Among 25 newly emerged workers examined, six still had some residual ovaries; however, no ovaries were found in the 30 middle-aged workers dissected.

\section{DISCUSSION}

Our results (Table I) permit two kinds of views concerning Meliponinae ovary development. First queen presence, as already verified by Zucchi (1993), does not have an inhibitory effect over worker ovary development, except perhaps in the case of $L$. muelleri, which behaves as A. mellifera, in this particular aspect. If there is any influence of the queen on worker ovary development, in most Meliponinae species, it is the stimulation of trophic egg development in the ovaries. The suggestion of this stimulatory effect comes from the fact that these eggs are pro- 


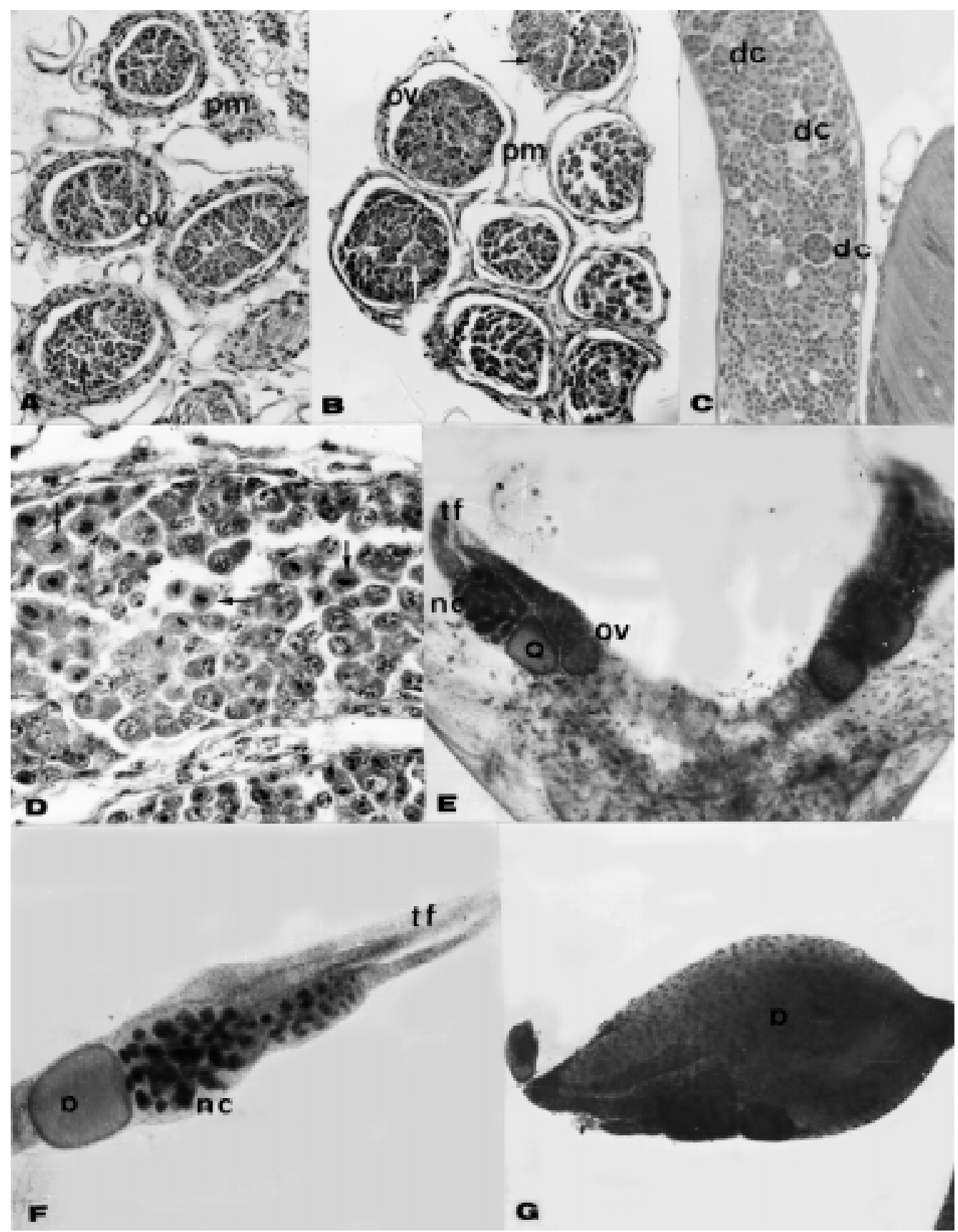

Figure 1 - Sections of virgin queen's ovaries. A, Cross section of dwarf queen ovary of Plebeia remota, showing four ovarioles. $B$, Cross section of normal-sized queen ovary of $P$. remota. The arrows point to early differentiating germinative cells. $C$, Longitudinal section of an ovariole of a dwarf queen of $P$. remota showing degenerating cysts (dc). D, Ovariole of Melipona quadrifasciata anthidioides showing cystocytes in mitosis (arrows). E, F, G, Feulgen reaction of whole mounted ovaries of workers of Leurotrigona mülleri (E), Scaptotrigona postica ( $\mathrm{F})$, and M. anthidioides $(\mathrm{G}) . \mathrm{nc}=$ Nurse cells; ov $=$ ovarioles; $\mathrm{o}=$ oocyte; $\mathrm{pm}=$ peritoneal membranes; $\mathrm{tf}=$ terminal filament.

duced first in the youngest workers, when they have contact with the queen, whereas functional eggs are produced by somewhat older nurse workers, that later come close to the brood cells. It is also possible that queen presence does not actually stimulate ovary development, but stimulates the development of trophic eggs in the ovaries or inhibits the production of functional eggs, which would only be produced away from the queen's influence, as is the case of orphan workers of L. muelleri or of older nurse workers of most Meliponine species.

The trophic egg, besides being bigger, seems to be somewhat less mature than the functional one (Cruz-Landim and Cruz-Höfling, 1971; Koedam et al., 1996). It is possible that queen presence stimulates yolk deposition in the oocyte and precocious ovulation by the worker, resulting in eggs with a more fragile, less structured chorion and 


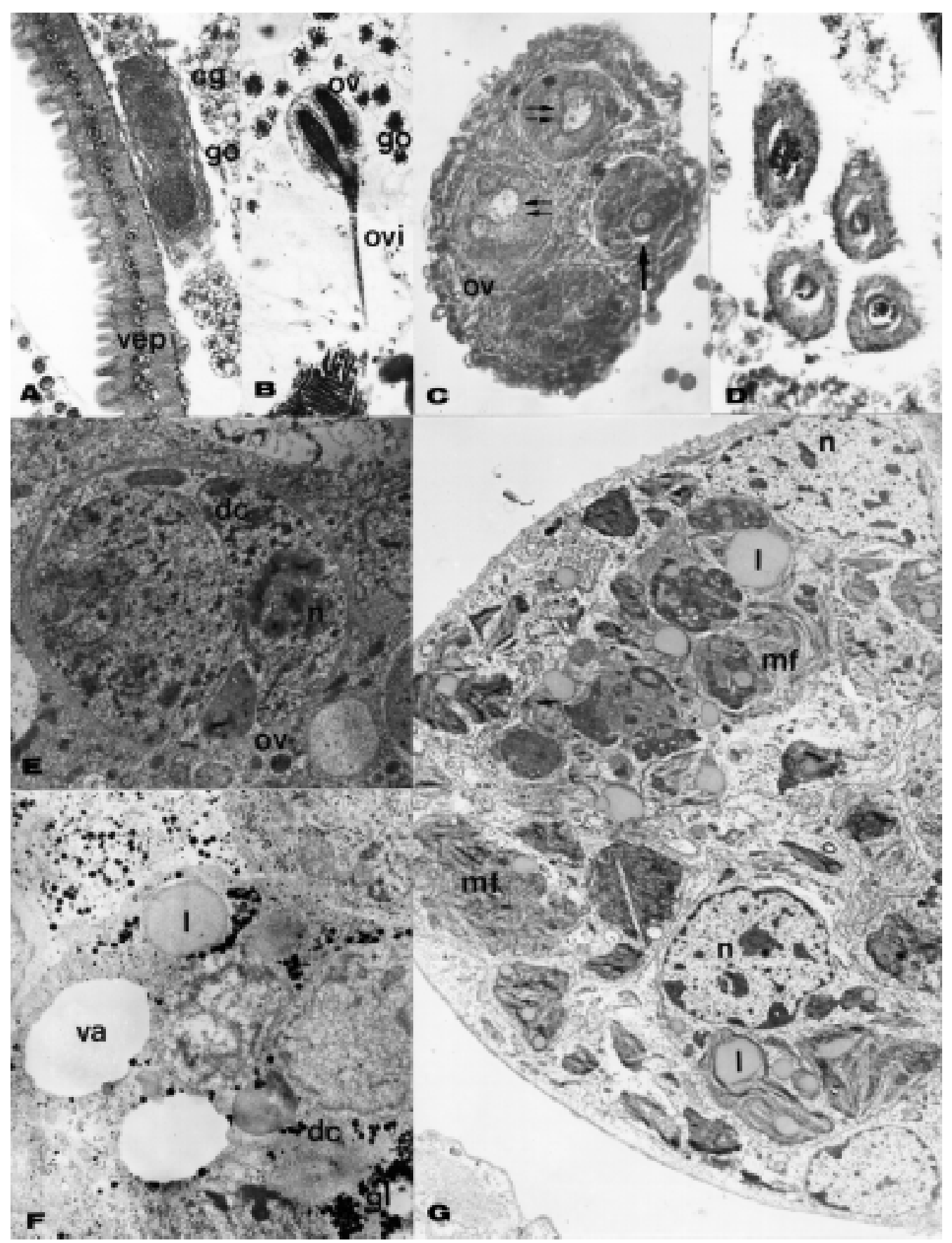

Figure 2 - Ovarian development in Frieseomelitta silvestri workers. A, Last larval stage. B, Prepupa. C, Brown-eyed pupa. Single arrow shows developing oocyte and double degenerating cells. D, Newly emerged worker. E, Electron micrography of an ovariole in last larval stage. F, TEM of an ovariole of brown-eyed pupa. G, Cross section TEM of an ovary of newly emerged worker. dc = Degenerating cells; $\mathrm{cg}=$ fat body; go = gonada $; 1=$ lipids $; \mathrm{mf}=$ myelin figures $; \mathrm{n}=$ nuclei ov = ovarioles; ovi = oviduto; va = vacuole; vep = ventricular epithelium; $\mathrm{gl}=\mathrm{glycogen}$.

shape alterations. The thin chorion facilitates digestion or egg content liberation for digestion. The capacity of queen Meliponinae to control worker ovary development seems to be far less than in A. mellifera, and the mechanism of this control, if it does exist, is unknown. Perhaps it acts on the endocrine glands via the nervous system.

The results presented here show that worker ovaries are able to develop and produce eggs in all species stud- ied except $F$. silvestri, in which the ovary is reabsorbed by a process similar to programmed cell death. This extreme condition is probably hormonally controlled. However, since queen determination in this species is trophic, ovary involution occurs in late pupae. An early involution would impair queen production.

There is a trend toward ovary degeneration in workers, which benefits the queen. Some of the eggs produced 
Table I - Ovarian development and egg production in worker Meliponine.

\begin{tabular}{|lcccc|}
\hline & \multicolumn{2}{c}{$\begin{array}{c}\text { Ovarian } \\
\text { development }\end{array}$} & \multicolumn{2}{c|}{$\begin{array}{c}\text { Time of } \\
\text { egg production } \\
\text { by workers }\end{array}$} \\
\cline { 2 - 6 } Species & $\begin{array}{c}\text { Queenright } \\
\text { colony }\end{array}$ & $\begin{array}{c}\text { Orphan } \\
\text { colony }\end{array}$ & $\begin{array}{c}\text { Trophic } \\
\text { eggs }\end{array}$ & $\begin{array}{c}\text { Fertile } \\
\text { eggs }\end{array}$ \\
\hline Melipona quadrifasciata & & & & \\
anthidioides & + & + & $\mathrm{YNW}$ & ONW \\
Trigona spinipes & + & + & $\mathrm{YNW}$ & $?$ \\
Plebeia remota & + & + & $?$ & ONW \\
Leurotrigona muelleri & - & + & - & $\mathrm{YNW}$ \\
Frieseomelitta silvestri & - & - & - & - \\
\hline
\end{tabular}

+ = Developed ovary; - = undeveloped ovary; YNW = young nurse worker; ONW = old nurse worker; ? = unknown condition.

by the workers are eaten by the queen caste. Trophic eggs are not only morphologically different (Koedam et al. 1996), but also have a different content. In S. postica, the trophic eggs laid seem to be immature compared to functional ones (Cruz-Landim and Cruz-Höfling, 1971). The same seems to occur in Melipona, since Koedam et al. (1996) observed an imperfect egg chorion pattern and a lack of the structure that permits the eggs to maintain an upright position in food in the brood cell at oviposition. These facts, added to the early production of this egg type, suggest an acceleration of its liberation from the ovary under the queen's influence.

On the other hand the production of males solely by the queens seems to be an evolutionary trend in bees (Michener, 1974; Zucchi, 1993). This tendency is exemplified by the complete sterilization of workers of the genera Frieseomelitta and Duckeola (Zucchi, 1993; Staurengo da Cunha et al., 1986, 1989, 1990). In this last case, absence of ovary development in workers is determined by factors acting during pupation, since early larvae have normal ovaries. According to our data, ovary involution starts in pupae and finishes in young adults.

Another important aspect is the number of ovarioles per queen ovary and its possible relationship with the caste determination model. The queen caste in Meliponinae may be determined genetically (Kerr, 1950, 1974) or trophically (Camargo, 1972; Campos et al., 1986). Queen size depends on the mechanism of caste determination. In trophically determined species, the queen is generally larger than the workers.

Genetically determined Melipona queens (Kerr, 1950) have four ovarioles in their ovaries as do dwarf queens and some normal-sized queens of $P$. remota (Cruz-Landim et al., 1998). However, some normal-sized queens of $P$. remota have six to eight ovarioles in each ovary, suggesting that food availability may influence ovariole number, as in A. mellifera. But the mechanism of the food effect in this case seems to be quite different, since in A. mellifera larval workers and queens have the same elevated number of ovarioles.
An indication that the course of the events in ovary developmental control is different in Apis and Meliponinae is that the number of ovarioles found in Meliponine workers is always four and in the presumed genetically determined queens it is also four, increasing if the caste is trophically determined. This indication needs further study to be confirmed at the morphological developmental level; ovariole numbers should be determined for a large number of Meliponinae species. However, in A. mellifera, as in the Meliponinae, the number of ovarioles per ovary may change under environmental influence (Camargo, 1972; Campos, 1993; Buschini and Campos, 1995 and CruzLandim et al., 1998). In trophic determination, the difference between A. mellifera and Meliponine is that in the former the worker larvae suffer food deprivation that results in partial castration, and in Meliponines the queens have an additional supply of food that may induce an increase in ovariole number. This is why dwarf and normal queens may be simultaneously present in some Meliponine species. It also explains how queens can be produced by topical application of juvenile hormone to larvae at the end of the larval stage (Imperatriz-Fonseca et al., 1997).

Therefore, we suggest that in the Meliponine queen presence stimulates more than inhibits ovary development in workers and does not influence the production of new queens.

The starting number of ovarioles during embryonic development is different in A. mellifera and Meliponinae. While in A. mellifera the larva starts with an elevated number of ovarioles, in Meliponines it seems to begin with only four. On account of this the main difference in trophically determined queens is the maintenance of the original number in A. mellifera queens, and the possibility of increase in Meliponines.

The results suggest that the genetic program for ovariole basic numbers is different in A. mellifera versus Meliponinae (hundreds in A. mellifera, only four in Meliponines). In both these numbers may be modified by differential feeding of the larvae.

\section{ACKNOWLEDGMENTS}

Research supported by FAPESP and CNPq. Publication supported by FAPESP.

RESUMO

Aspectos morfológicos indicativos do grau de desenvolvimento dos ovários de meliponíneos indicaram um possível efeito estimulador da rainha sobre o desenvolvimento do ovário e a produção de ovos tróficos em algumas espécies. Há também indicações de que a rainha inibe a produção de ovos férteis pelas operárias. Esta inibição pode caracterizar-se por um retardamento na postura de ovos férteis, até que a operária esteja fora do contacto direto com a rainha, ou por um não desenvolvimento dos ovários na sua presença, como visto em Leutrotrigona muelleri. A tendência evolutiva, para uma total inabilidade para a 
produção de ovos férteis pelas operárias, tem sua representação extrema na reabsorção do ovário na pupa, como ocorre em Frieseomelitta silvestri. Por outro lado, a presença, em algumas espécies com determinação trófica das castas, de rainhas anãs com o número básico (quatro) de ovaríolos nos ovários, ao lado de rainhas normais, determinadas troficamente, com números maiores de ovaríolos em seus ovários demonstra a influência do alimento sobre este caráter, como em Apis mellifera.

\section{REFERENCES}

Beig, D. (1972). Social regulation in Nannotrigona (Scaptotrigona) postica. J. Apicult. Res. 11:33-39.

Buschini, M.L.T. and Campos, L.O. (1995). Caste determination in Trigona spinipes (Hymenoptera, Apidae); influence of available food and juvenile hormone. Rev. Bras. Biol. 55: 121-129.

Butler, C.G. (1957). The control of ovary development in worker honeybees (Apis mellifera). Experientia 13: 256.

Camargo, C.A. (1972). Determinação das castas em Scaptotrigona postica Latreille (Hymenoptera, Apidae). Rev. Bras. Biol. 32: 133-138.

Camargo, J.M.F. (1974). Notas sobre a morfologia e a biologia de Plebeia (Schwarziana) quadripunctata quadripunctata (Hymenoptera, Apidae, Meliponinae). Stud. Entomol. 17: 433-470.

Camillo-Atique, C. (1977). Estudo da variabilidade etológica de Friesella incluindo a caracterização de espécies crípticas (Hym. Meliponinae). Tese de Doutorado, Faculdade de Medicina de Ribeirão Preto, USP, Ribeirão Preto, SP.

Campos, L.O. (1993). Determinação do sexo em abelhas. XXX. Influência da quantidade de alimento e do hormônio juvenil na determinação de castas em Partamona cupira helleri (Hymenoptera, Apidae, Meliponinae). Rev. Bras. Zool. 10: 449-452.

Campos, L.O., Faria, G.M., Pires, C.S.S., Drummond, M.S. and Lacerda, L.M. (1986). Determinação de castas em Nannotrigona testaceicornis. Anais do III Congresso Brasileiro de Zoologia, Cuiabá, MT, Brasil, p. 38.

Cruz-Landim, C. and Cruz-Höfling, M.A. (1971). Cytochemical and ultrastructural studies on eggs from workers and queen of Trigona. Rev. Bras. Pesqui. Med. Biol. 4: 19-25.

Cruz-Landim, C., Reginato, R.D. and Imperatriz-Fonseca, V.L. (1998). Variation on ovariole number in Meliponinae (Hymenoptera, Apidae) queen's ovaries, with comments on ovary development and caste differentiation. Pap. Avulsos Zool. 40: 289-296.

Groot, A.P. and Voogd, S. (1954). On the ovary development in queenless worker bees (Apis mellifera L.). Experientia 10: 384-385.

Hartfelder, K. and Steinbrück, G. (1997). Germ cell cluster formation and cell death are alternatives in caste-specific differentiation of the larval ovary. Invertebr. Reprod. Dev. 31:237-250.

Imperatriz-Fonseca, V.L., Cruz-Landim, C. and Silva de Moraes, R.L.M. (1997). Dwarf genes in Nannotrigona testaceicornis (Apidae, Meliponinae, Trigonini). Behaviour, exocrine gland morphology and reproductive status. Apidologie 28: 113-122.

Iwata, K. and Sakagami, S.F. (1966). Gigantism and dwarfism in the eggs in relation to the modes of life, with notes on the number of ovarioles.
Jpn. J. Evol. 16: 4-16.

Juliani, L. (1962). O aprisionamento de rainhas virgens em Trigonini. Bol. Univ. Paraná Zool. 20: 1-11.

Kerr, W.E. (1950). Genetic determination of castes in the genus Melipona. Genetics 35: 143-152.

Kerr, W.E. (1974). Sex determination in bees. III. Caste determination in Melipona and genic control. Insectes Soc. 21: 357-368.

Kerr, W.E., Stort, A.C. and Montenegro, M.J. (1966). Importância de alguns fatores ambientais na determinação das castas do gênero Melipona. An. Acad. Bras. Ciênc. 30: 149-168.

Koedam, D., Velthausz, P.H., Krift, T.V.D., Dohmen, M.R. and Sommeiher, M.J. (1996). Morphology of reproductive and trophic eggs and their controlled release by workers in Trigona (Tetragonisca) angustula. Illiger (Apidae, Meliponinae). Physiol. Entomol. 21: 289-296.

Kubisova, S. and Hasbachova, H. (1978). Effects of larval extracts on the development of ovaries in caged worker honeybees. Acta Ent. Bohemoslov. 75: 9-14.

Kubisova, S., Hasbachova, H. and Urkow, J. (1982). Effects of fractions of larval extracts on the development of ovaries in caged worker honeybees. Acta Ent. Bohemoslov. 79: 334-340.

Michener, C.D. (1974). The social behavior of the bees. A comparative study Harvard University Press, Cambridge, MA, p. 404.

Sakagami, S.F. and Zucchi, R. (1968). Oviposition behavior of an Amazonic stingless bee, Trigona (Duckeola) ghilianii. J. Fac. Sci. Hokkaido Univ. Ser. VI Zool. 16: 564-581.

Sakagami, S.F., Beig, D. and Akahira, Y. (1963). Occurrence of ovary developed workers in queenright colonies of stingless bees. Rev. Bras. Biol. 23: 115-129.

Staurengo da Cunha, M.A. (1978). Desenvolvimento ovariano em operárias adultas de Scaptotrigona postica Latreille. III. Aspectos histológicos e histoquímicos. Pap. Avulsos Zool. 32: 71-86.

Staurengo da Cunha, M.A. and Campos, L.A.O. (1990). Desenvolvimento ovariano em operárias de Frieseomelitta varia varia (Lep. 1836) (Hymenoptera, Apidae). Rev. Bras. Biol. 53: 63-69.

Staurengo da Cunha, M.A., Gomes, G.M. and Campos, L.A.O. (1986). Desenvolvimento ovariano em operárias adultas de Frieseomelitta silvestri languida (Hymenoptera, Apidae) sob condições normais e de orfandade. Ciênc. Cult. 38: 1725-1736.

Staurengo da Cunha, M.A., Cunha, R.A. and Pimentel, M.A.L. (1989). Relação entre o desenvolvimento dos ovários e atividade dos corpora allata em operárias de Frieseomelitta silvestri languida (Hymenoptera, Apidae). Rev. Bras. Zool. 6: 245-254.

Terada, Y. (1974). Contribuição ao estudo da regulação social em Leurotrigona muelleri e Frieseomelitta varia varia (Hym. Apidae). Tese de Mestrado, Faculdade de Medicina de Ribeirão Preto, USP, Ribeirão Preto, SP.

Zucchi, R. (1993). Ritualized dominance, evolution of queen-worker interactions and related aspects in stingless bees (Hymenoptera, Apidae). In: Evolution of Insect Societies (Inoue, T. and Yamane, S., eds.). Hakuhin-sha, Tokyo, pp. 207-249.

Zucchi, R. (1994). A evolução do processo de tratamento das células de cria de Meliponinae: do antagonismo à dominância ritualizada (Hymenoptera, Apidae). Anais do Encontro sobre Abelhas, Ribeirão Preto, SP, 1:38-45.

(Received March 6, 1998) 